\title{
THE ENERGY EFFICIENCY OF ELECTRIC ENERGY AS A TRACTION USED IN TRANSPORT
}

\begin{abstract}
The article deals with the problem of electric power production in terms of environmental impact, in particular the energy efficiency of its production to utilize primary sources. The efficiency of its production directly depends on the composition of primary sources and technologies used. Difference in efficiency by converting various forms of energy into electrical power and their ratio in the use directly affect the resulting efficiency, production of emissions and thus the environmental impact. Electric traction, its production, is burdened less efficient than other types of tractions used in transport, but at the final reconciliation of their consumption in vehicles, this difference decreases or delays because the vehicles themselves work with different conversion efficiency of its traction on mechanical work, vehicle driving.
\end{abstract}

Keywords: production efficiency, electric traction, primary sources, well-to-wheels, carbon fuel

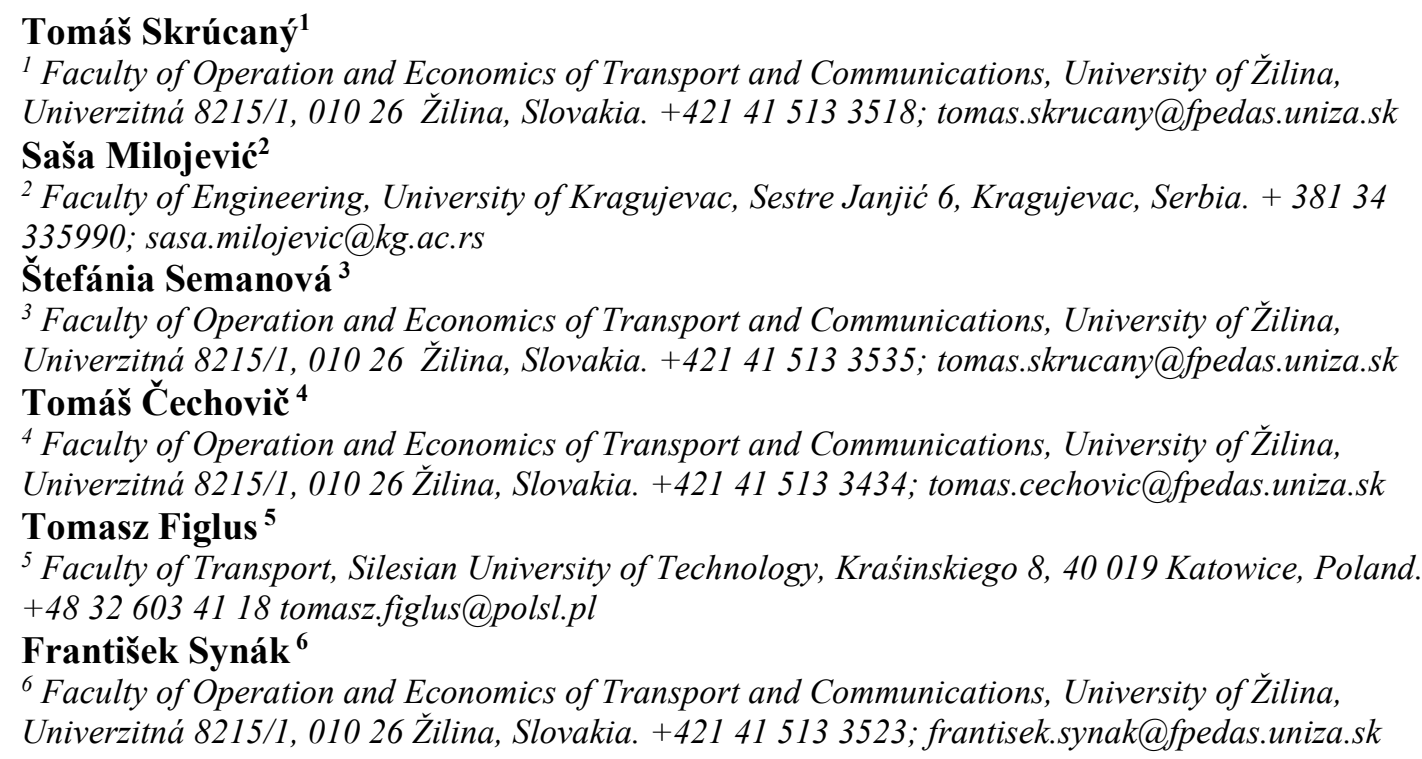

\section{Introduction}

The current economic situation is directly dependent on transport. Without having the possibility of transporting goods or without transport service provision to the population, it would not be possible to carry out other follow-up activities aimed at creating the value of products or services which satisfy the society or an individual.

In the transport process, the input energy is converted into the movement of transport vehicles which provide the required spatial relocation of goods and persons. Therefore, transport is dependent on energy supply. Today's transport is largely dependent on oil because the majority of transport vehicles is propelled by engines combusting petroleum products - hydrocarbon fuels. This particularly relates to road, air and water transport. Most of transport vehicles of rail transport are currently powered by electric traction motors. Therefore, the degree of dependence of this type of transport on oil is lower than in the case of previously mentioned transport modes. However, the fact is that electric energy is produced by using petroleum products or coal in most states. All these natural resources are non-renewable and their stocks are constantly decreasing. Given to the mentioned facts, there is the effort to make transport more efficient in the field of energy dependence (Rybicka, I. et al. 2018, Milojević, S. et al. 2018, Milojevic, S., Pesic, R. 2012, Milojević, S. 2017, Ližbetin, J., Hlatká, M., Bartuška, L. 2018).

\section{Standard EN 16258: 2012 and its using in calculations}

This European Standard specifies general methodology for calculation and declaration of energy consumption and greenhouse gas emissions (GHG) in connection with any services (cargo, passengers or both). It specifies general principles, definitions, system boundaries, methods of calculation, allocation rules (allocation, assignment) and recommendations on information to support standardized, accurate, reliable and verifiable declarations regarding energy consumption and greenhouse gas emissions associated with any freight services. It also contains examples of these principles use. The calculation for one given transport service must be performed using the following three main steps (European standard EN 16 258:2012): 
- Step 1: Identification of the various sections of the service;

- Step 2: Calculation of energy consumption and greenhouse gas emissions for each section;

- Step 3: Sum the results for each section.

The standard does not consider only the production of the secondary emissions and energy consumed during the combustion of the fuel (energy conversion from fuel to mechanical energy) but as well as primary, incurred in the extraction, production and distribution:

- $\mathrm{e}_{\mathrm{w}}$ - well-to-wheels energetic factor for defined fuel;

- $g_{w}$ - well-to-wheels emissions factor for defined fuel;
- $e_{t}$ - tank-to-wheels energetic factor for defined fuel; and

- $g_{t}$ - tank-to-wheels emissions factor for defined fuel.

Well-to-wheels is "well on wheels" and also covered primary and secondary emissions and consumption. This factor is somewhere also called as LCA (life-cycleanalysis).

Tank-to-Wheels factor is thinking only of secondary emission and consumption.

This Standard specifies general methodology for calculation and declared value for the energetic factor and factor in greenhouse gas emissions must be selected in accordance with Annex A (European standard EN 16 258:2012).

Table 1. Energy factors of chosen fuels

\begin{tabular}{|c|c|c|c|c|c|c|c|c|c|c|}
\hline \multirow{3}{*}{ Fuel type } & \multicolumn{4}{|c|}{ Energy factor } & \multicolumn{6}{|c|}{ Emission factor } \\
\hline & \multicolumn{2}{|c|}{$\begin{array}{c}\text { Tank-to-wheels } \\
\left(e_{t}\right)\end{array}$} & \multicolumn{2}{|c|}{$\begin{array}{c}\text { Well-to-wheels } \\
\left(\mathrm{e}_{\mathrm{w}}\right)\end{array}$} & \multicolumn{3}{|c|}{ Tank-to-wheels $\left(\mathrm{g}_{\mathrm{t}}\right)$} & \multicolumn{3}{|c|}{ Well-to-wheels $\left(g_{w}\right)$} \\
\hline & kg & MJ/I & kg & $\mathbf{M J} / \mathbf{I}$ & $\begin{array}{c}\mathrm{gCO}_{2} \mathrm{e} / \\
\mathrm{MJ}\end{array}$ & $\begin{array}{c}\mathrm{kgCO}_{2} \mathrm{e} / \\
\mathrm{kg}\end{array}$ & $\mathrm{kgCO}_{2} \mathrm{e} / \mathbf{l}$ & $\begin{array}{c}\mathbf{g C O}_{2} \mathbf{e} / \\
\mathrm{MJ}\end{array}$ & $\underset{/ \mathrm{kg}}{\mathrm{kgCO}_{2} \mathrm{e}}$ & $\mathrm{kgCO}_{2} \mathrm{e} / \mathrm{l}$ \\
\hline Gasoline & 43.2 & 32.2 & 50.5 & 37.7 & 75.2 & 3.25 & 2.42 & 89.4 & 3.86 & 2.88 \\
\hline Diesel & 43.1 & 35.9 & 51.3 & 42.7 & 74.5 & 3.21 & 2.67 & 90.4 & 3.90 & 3.24 \\
\hline $\mathrm{CNG}$ & 45.1 & & 50.5 & & 59.4 & 2.68 & & 68.1 & 3.07 & \\
\hline
\end{tabular}

Emission gases are composed of several individual components (gas). Each of them have different chemical and physical properties, so they otherwise participate in environmental degradation. In order to compare emissions from different activities, fuels, vehicles where emissions have different impact, one representative unit used in the comparison must be designated (Lizbetin, J., Stopka, O., Nemec, F. 2016, Stoilova, S. 2016). This is the $\mathrm{CO}_{2}$ equivalent which is a measure of the impact of specific emissions and likens it to the impact of $\mathrm{CO}_{2}$. The label is $\mathrm{CO}_{2 \mathrm{e}}$ (equivalent).

\section{Well-to-wheels energy and emission factors}

Well-to-wheels factors used for electricity must be ones of the following data, provided that the selected data involves all previous operating processes in accordance with the objectives of this standard or they are corrected in order to take into account the contribution of missing processes and gases. This list is given by the following order:

- the value specified by the electricity supplier for purchased electricity from the certified production,

- the value of purchased electricity, specified by the electricity supplier for its production in the relevant electrical distribution system within which the transport is carried out,

- as the last option - the average value for electricity supplied to consumers in the relevant electrical distribution system within which the transport is carried out.

In order to avoid double counting in, the electricity supplier should deduct the electricity sold from the certified production from the remaining average selling electricity. The relevant electrical distribution system may be either national or one of several unconnected systems in a country or the system utilized by several countries. The relevant units should specify the identification of relevant electrical distribution systems (at least in Europe) (European standard EN 16 258:2012, Skrucany, T., Gnap, J. 2014, Technical annex to the SEAP template instructions document: The emission factors).

Tank-to-wheels energy factor $\left(e_{t}\right)$ for electricity equals to $3.6 \mathrm{MJ} / \mathrm{kWh}$ and tank-to-wheels emission factor $\left(\mathrm{g}_{\mathrm{t}}\right)$ for electricity is equal to zero (European standard EN 16 258:2012).

\section{Energy production}

Energy and emission factor (WtW) takes into account the partial losses in the production and distribution of electricity in the chain:

1. composition of energy sources used in the electricity production;

2. efficiency of the electricity production from individual sources;

3. efficiency of the transmission (distribution) of electricity to the final consumer. 
Based on the above, it can be concluded that efficiency of electricity is directly dependent on the electricity production technology, composition and shares of individual sources and distribution efficiency.

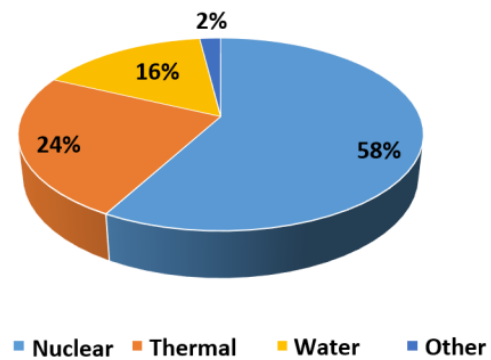

Fig. 1. The share of primary sources in electricity production in Slovakia in 2015 (Eurostat)

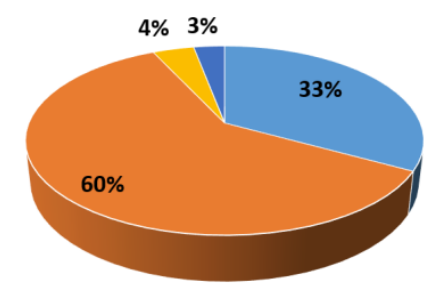

" Nuclear $=$ Thermal $\quad$ Water $=$ Other

Fig. 2. The share of primary sources in electricity production in the Czech Republic in 2015 (Eurostat)

Energy efficiency in electricity production can be calculated as the weighted arithmetic mean of the shares of primary sources and the efficiencies in production of electric energy of individual sources. The weights of values represent the shares of individual sources. The values of efficiency were chosen based on the national regulation which prescribes their height (Vyhláška č. 88/2015 Z.z.).

The power produced is delivered to the consumer through the transmission system. This process is realized with losses and the efficiency of electricity transmission in the grid of the Slovak Republic was at the level of approximately $93 \%$ (Report of the company SPS, a. s.).

Other losses in the electricity transmission onto the wheels of the transport vehicle lie in its own efficiency. The losses in the transport vehicle are caused by the transmission through trolley poles or pantograph (trolleybuses and locomotives, respectively) or from batteries (electric vehicles) to the control system, engine, gears and wheels. The efficiency of this process depends on the powertrain technology, but it is usually about $90 \%$ (without taking into account the efficiency of electric motor consumption in relation to its speed).

Thus, the overall energy efficiency of delivered electricity in transport is:

$$
\eta_{=} \eta_{\text {Prod }} \cdot \eta_{\text {Trans }} \cdot \eta_{V e h}=\frac{\sum\left(\eta_{S i} \cdot p_{S i}\right)}{\sum p_{S}} \cdot \eta_{\text {Trans }} \cdot \eta_{V e h}
$$

Where:

$\eta \quad$ overall energy efficiency (-)

$\eta_{\text {Prod }}$ efficiency of electricity production (-)

$\eta_{\text {Trans }}$ efficiency of electricity transmission (-)

$\eta_{\text {Veh }}$ efficiency of vehicle (-)

$\eta_{\mathrm{Si}} \quad$ efficiency of a particular primary source (-)

$\mathrm{p}_{\mathrm{Si}} \quad$ share of a particular source in the electricity production (-)

ps sum of partial shares of individual sources (-)

Given to the above mentioned fact and the partial share of individual efficiencies on the overall efficiency, the electricity production is normally burdened with the efficiency of 30-50\%. This means in some cases that three times more energy is used in electricity production than the final consumer consumes. The overall efficiency is to the greatest extent burdened with primary sources and electricity production technology. The consumer is often unable to determine the efficiency of the transport vehicle; however, it is reflected in the final consumption (e.g. when recharging batteries). If we neglect this efficiency and consider the electricity taken from the grid, thus in addition to the efficiency of electricity production, the electricity transmission has only minimal losses (around 7-8\%). The efficiency of electricity production is directly dependent on the used primary sources and technology their transformation into electricity. In the absence of declaration of electricity production efficiency, the calculation on the basis of the data on the shares of individual sources and technology is possible. For electricity production in the SR, the data from the Decree regulating the lowest efficiencies of operated power plants were used as inputs (Vyhláška č. 88/2015 Z.z.). The selected values of efficiency are given in Table 2. 
Table 2. Energy efficiency values of energy conversion for electricity generating devices

\begin{tabular}{|c|c|c|c|c|c|}
\hline \multirow{5}{*}{$\begin{array}{c}\text { Electricity } \\
\text { generating device }\end{array}$} & \multirow{5}{*}{ Fuel } & \multirow{3}{*}{ Electrical power } & \multicolumn{3}{|c|}{ Year of introducing the device into operation } \\
\hline & & & till 1998 & $1998-2012$ & $2013-2015$ \\
\hline & & & \multicolumn{3}{|c|}{ efficiency (\%) } \\
\hline & & \multirow{2}{*}{ (MW) } & \multicolumn{3}{|c|}{ operational } \\
\hline & & & - & - & - \\
\hline \multirow{12}{*}{$\begin{array}{l}\text { Combustion device } \\
\text { and condensing steam } \\
\text { turbine }\end{array}$} & \multirow{3}{*}{ black coal } & to 15 & 36 & 36 & 38 \\
\hline & & from 15 including to 50 & 38 & 38 & 40 \\
\hline & & 50 and higher & 39 & 39 & 41 \\
\hline & \multirow{3}{*}{ brown coal } & to 15 & 35 & 35 & 37 \\
\hline & & from 15 including to 50 & 37 & 37 & 39 \\
\hline & & 50 and higher & 38 & 38 & 40 \\
\hline & \multirow{3}{*}{ natural gas } & to 10 & 38 & 38 & 40 \\
\hline & & from 10 including to 35 & 40 & 40 & 42 \\
\hline & & 35 and higher & 41 & 41 & 43 \\
\hline & \multirow{3}{*}{ heavy fuel oil } & to 15 & 36 & 36 & 38 \\
\hline & & from 15 including to 50 & 38 & 38 & 40 \\
\hline & & 50 and higher & 39 & 39 & 41 \\
\hline \multirow{6}{*}{$\begin{array}{l}\text { Heat source and } \\
\text { condensing steam } \\
\text { turbine }\end{array}$} & \multirow{3}{*}{ nuclear } & to 500 & 31 & 31 & 32 \\
\hline & & from 500 including to 1000 & 31 & 31 & 32 \\
\hline & & 1000 and higher & 31 & 31 & 32 \\
\hline & \multirow{3}{*}{$\begin{array}{l}\text { heat from industrial } \\
\text { processes }\end{array}$} & to 10 & 36 & 36 & 36 \\
\hline & & from 10 including to 35 & 36 & 36 & 36 \\
\hline & & 35 and higher & 36 & 36 & 36 \\
\hline Combustion engine & Natural gas & to 0.05 & 29 & 29 & 29 \\
\hline
\end{tabular}

Source: (Edict no. 88/2015 Z.z., author)

Based on the above values of efficiency and composition of primary sources, the electricity production efficiency was $42 \%$ in the SR in 2015 and $37 \%$ in the Czech Republic. This means that if the final consumer consumed $100 \mathrm{kWh}$ of electricity, the actual consumed energy was at the level of $240 \mathrm{kWh}$ in the SR and 270 $\mathrm{kWh}$ in the Czech Republic. As mentioned, this value of overall efficiency significantly differs according to the used primary sources whose own efficiency are different. The efficiency of energy conversion to electricity in steam turbines is approximately $30 \%$ for nuclear power, $35 \%$ for coal and $40 \%$ for natural gas. Photovoltaic cells achieve the efficiency of around 10-20\% (it depends on the technology and sunlight). However, hydroelectric power plants are the most efficient because they operate only with losses of about $20 \%$ (smaller plants) (Electropedia, Decarbonisation Pathways). Thus, if a country used only this source of energy, the efficiency of electricity production would achieve the level of around $80 \%$. From this reason, the counties using the energy of watercourses for electricity production utilize the least burdensome energy in terms of energy intensity as well as $\mathrm{CO}_{2}$ production.

Table 3. Comparison of energy intensity of fuels

\begin{tabular}{|c|c|c|c|c|c|}
\hline Fuel & $\begin{array}{l}\text { direct energy } \\
\text { consumption } \\
\text { (MJ) }\end{array}$ & $\begin{array}{c}\text { direct energy } \\
\text { consumption } \\
\quad(\mathrm{kWh})\end{array}$ & $\begin{array}{l}\text { Weight unit } \\
\text { (kg) }\end{array}$ & $\begin{array}{l}\text { Volume unit } \\
\text { (I) }\end{array}$ & $\begin{array}{l}\text { Overall energy } \\
\text { consumption } \\
(\mathbf{W}-\mathbf{t}-\mathbf{W}) \\
(\mathbf{k W h})\end{array}$ \\
\hline Petrol & \multirow{6}{*}{100} & \multirow{6}{*}{28} & - & 3.1 & 32.8 \\
\hline $\mathrm{CNG}$ & & & 2.2 & - & 31.4 \\
\hline Diesel & & & - & 2.8 & 33.3 \\
\hline \multirow{3}{*}{ Electricity } & & & \multicolumn{2}{|c|}{ Country } & - \\
\hline & & & \multicolumn{2}{|c|}{$\mathrm{CZ}$} & 75.7 \\
\hline & & & \multicolumn{2}{|c|}{ SK } & 66.7 \\
\hline
\end{tabular}

Source: (European standard EN 16 258:2012, Technical annex to the SEAP, Skrucany, T., Gnap, J. 2014, Eurostat)

Table 4 compares fuel types or traction of transport vehicles in terms of their energy intensity. The same amount of consumed energy i.e. $100 \mathrm{MJ}$ or $28 \mathrm{kWh}$ is used for the comparison. Subsequently, the quantities of liquid and gaseous fuels in which this amount of energy is present are given. The right column of the table contains the calculation of the total energy of individual types of traction, i.e. the energy contained in the unit quantity together with the energy needed to its production. The right column shows the effectiveness of individual types of traction; however, it represents a comparison of their energy efficiency in terms of their physical properties and technological processes of their production (Jurkovic, M., Kalina, T., Teixeira, A. F. 
2017, Petro, F., Konecny, V. 2017) During the consumption i.e. energy conversion to mechanical work in the transport vehicle, the process is realized with different efficiency. Transport vehicles propelled by petrol, diesel or CNG operate mostly with the efficiency of $30-45 \%$ while transport vehicles using electric traction achieve the efficiency of $80-90 \%$ (see the table below) (Skrucany, T., Gnap, J. 2014, Vyhláška č. 88/2015 Z.z., Knez, M. et. al. 2014, Kalina, T., Jurkovic, M., Grobarčíková, A. 2015).

Table 4. Calculation of energy consumption and GHG production of chosen passenger car

\begin{tabular}{|c|c|c|c|c|c|c|}
\hline \multirow[b]{2}{*}{ Fuel } & \multirow[b]{2}{*}{$\begin{array}{l}\text { Ø fuel consumption } \\
\text { (l. } \mathrm{kg} . \mathrm{kWh} / 100 \mathrm{~km})\end{array}$} & \multicolumn{3}{|c|}{ T-t-W } & \multicolumn{2}{|c|}{ W-t-W } \\
\hline & & $\begin{array}{c}\text { Energy } \\
\text { consumption } \\
(\mathrm{MJ} / \mathbf{k m})\end{array}$ & $\begin{array}{c}\text { Energy } \\
\text { consumption } \\
(\mathbf{k W h} / \mathbf{k m})\end{array}$ & $\begin{array}{c}\text { Production of } \\
\mathrm{CO}_{2 \mathrm{e}} \\
(\mathrm{g} / \mathrm{km})\end{array}$ & $\begin{array}{c}\text { Energy } \\
\text { consumption } \\
(\mathrm{MJ} / \mathbf{k m})\end{array}$ & $\begin{array}{c}\text { Production of } \\
\mathrm{CO}_{2 \mathrm{e}} \\
(\mathrm{g} / \mathrm{km})\end{array}$ \\
\hline Petrol & 8.07 & 2.60 & 0.72 & 195 & 3.04 & 232 \\
\hline $\mathrm{CNG}$ & 5.17 & 2.33 & 0.65 & 139 & 2.59 & 159 \\
\hline Diesel & 6.12 & 2.20 & 0.61 & 163 & 2.61 & 198 \\
\hline Electric* & 21.04 & 0.76 & 0.21 & 0 & $1,8 / 2,05$ & $74 / 178$ \\
\hline Hybrid** & 5.4 & 1.74 & 0.48 & 131 & 2.04 & 156 \\
\hline
\end{tabular}

Source: (Electropedia)

* this applies only for consumed electricity produced in the SR or (/) CZ

** variable value, it greatly depends on the vehicle operation (city, highway), the type of hybrid technology used

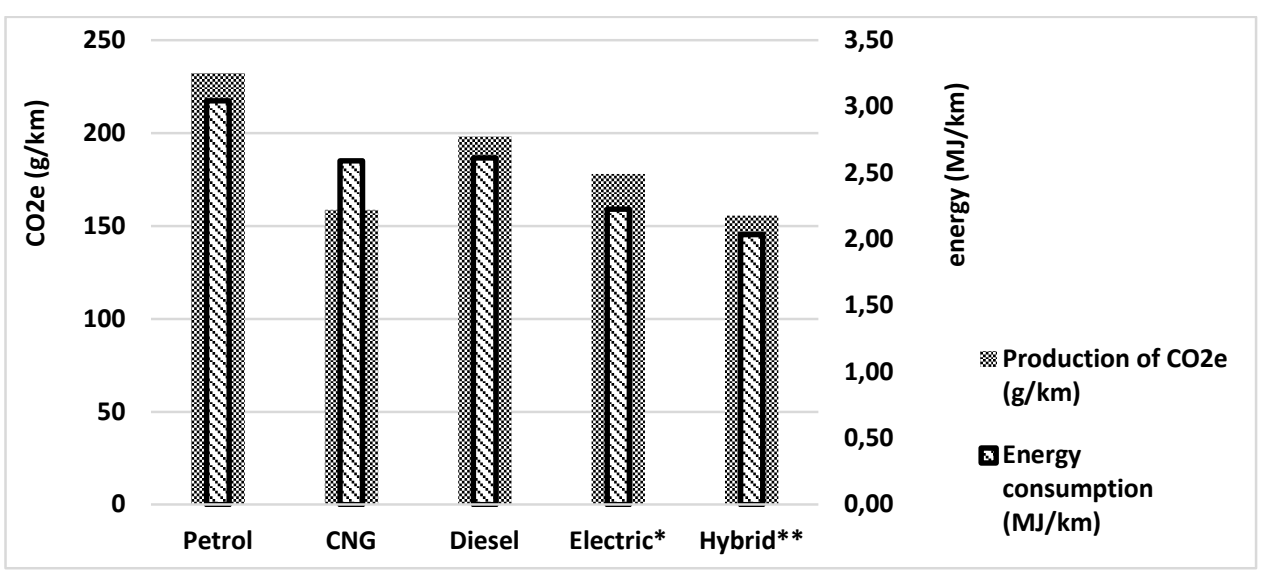

Fig. 3. Results of energy consumption and GHG production of chosen passenger car

The results presented in the table represent the energy consumption and GHG productions from global perspective i.e. primary as well as secondary impacts are considered. The results of electric energy consumption (column "Electric") are introduced in this graphical expression only for one evaluated country - the Czech Republic - not for Slovakia. When considering hydrocarbon fuels, the CNG propulsion is the cleanest in terms of GHG production.

This results are calculated from values of fuel and energy consumption of vehicles operated in real driving conditions. These values of consumption were used form database of almost 1200 vehicles - passenger cars with gross vehicle $1.9 \mathrm{t}$ operated in Europe (Database of real vehicle fuel consumption). The vehicle database consists of two different marks and types which are sold in all type of engines.

However, it represents less efficient fuel in terms of energy consumption, even though it is fuel whose production is not subjected such procedures as in the case of petrol or diesel. This is caused by a high energy content in $1 \mathrm{~kg}$ of $\mathrm{CNG}$, so engines combusting $\mathrm{CNG}$ achieve less efficiency than engines combusting petrol or diesel (Polcar, A., Cupera, J., Kumbar, V. 2016, Šarkan, B. et al. 2017, Hlatká, M., Bartuška, L. 2018).

\section{Conclusions}

Different types of traction used in transport are specific in their characteristics which are manifested during their consumption. Each type has its advantages and disadvantages. As it is with electric traction, which production is less effective compared to gas or oil fuels (Table 3), but efficiency of vehicles is higher, therefore the final energy consumption is at a level similar to the comparison of fuel (Table 4 and Fig. 3). Electricity production efficiency as well as its emissions production are directly dependent on the use of primary sources (Fig. 1, 2 and Fig. 3), therefore the countries should take into account their composition and especially the use of technology. If they use the right composition and new technology of electricity production, they can produce 
actually constitutes acceptable electrical traction for the environment that is not a casual case today. Hydropower plants have the highest efficiency of electricity generation. They also produce minimal emissions, almost none. They are therefore considered to be the most acceptable form of energy production in keeping the right integration into the country, unhindered migratory routes of animals. Therefore it can be considered as a "green" electric traction in countries such Norway, Sweden, Austria and Switzerland. In contrast, countries as Estonia, Poland and Greece mainly use fossil fuels to generate electricity. Electric traction, its production is burdened less efficient than other types of tractions used in transport, but it is true only if we compare the energy efficiency due to their physical properties and technological processes for their production. During of their consumption, that is the conversion to mechanical work in vehicles, this phenomenon has a different effectivity. Vehicles driven by oil and gas products work mostly with effectivity from 30 to $45 \%$, vehicles used electric traction force reached $80-90 \%$, so the difference in the efficiency of their production is ultimately suppressed.

\section{References}

Database of real vehicle fuel consumption; https://www.spritmonitor.de

Decarbonisation Pathways, publication of Eurelectric (iniciative of energy industry in Europe, December 2018; https://cdn.eurelectric.org/media/3457/decarbonisationpathways-h-5A25D8D1.pdf

Electropedia - Battery and Energy Technologies - Energy Efficiency; https://www.mpoweruk.com

European standard EN 16 258:2012 Methodology for calculation and declaration of energy consumption and GHG emissions of transport services (freight and passengers).

Eurostat, Europan statistics portal

Hlatká, M., Bartuška, L. 2018 Comparing the Calculations of Energy Consumption and Greenhouse Gases Emissions of Passenger Transport Service. In: Nase More, Dubrovnik: University of Dubrovnik, Vol. 65, Issue 4, p. 224-229. ISSN 0469-6255.

Jurkovic, M., Kalina, T., Teixeira, A. F. 2017 Possibilities of using alternative fuels for transport solution in Brazil. In: Proceedings of the 21st international scientific conference Transport means 2017, Kaunas, Lithuania, 2017, p. 724728.

Kalina, T., Jurkovic, M., Grobarcikova, A. 2015 LNG - Great Opportunity for the Inland Water Transport. In: Proc. of the 19th intern. scientific conference: Transport Means 2015, October 22-23, Kaunas University of Technology, p. 489-492.

Knez, M. et. al. 2014. The estimation of a driving cycle for Celje and a comparison to other European cities. In. Sustainable cities and society, Vol. 11, p. 56-60.

Lizbetin, J., Stopka, O., Nemec, F. 2016 Methodological Assessment of Environmental Indicators in Combined Transport in Comparison with Direct Road Freight Transport. In: Proceedings of the 20th international scientific conference Transport means 2016, Kaunas, Lithuania, p. 151-155.
Ližbetin, J., Hlatká, M., Bartuška, L. 2018 Issues concerning declared energy consumption and greenhouse gas emissions of FAME biofuels. In: Sustainability (Switzerland), 10(9).

Milojevic, S., Pesic, R. 2012 Theoretical and experimental analysis of a CNG cylinder rack connection to a bus roof, In: International Journal of Automotive Technology, Vol.13, No.3, p. 497-503, ISSN 1976-3832, DOI: 10.1007/s12239-012-0047-y

Milojević, S. 2017 Sustainable application of natural gas as engine fuel in city buses - benefit and restrictions, In: Journal of Applied Engineering Science, Vol.15, No.1, p. 81-88, ISSN 1451-4117, DOI: 10.5937/jaes15-12268

Milojević, S. et al. 2018 Alternative drive systems and environmentaly friendly public passengers transport, In: Applied Engineering Letters, Vol.3, No.3, p. 105-113, ISSN 2466-4847, DOI: https://doi.org/10.18485/aeletters.2018.3.3.4

Petro, F., Konecny, V. 2017 Calculation of emissions from transport services and their use for the internalisation of external costs in road transport. In: 12th International scientific conference of young scientists on sustainable, modern and safe transport, High Tatras, Slovakia, Procedia Engineering, Vol. 192, p. 677-682. DOI: 10.1016/j.proeng.2017.06.117.

Polcar, A., Cupera, J., Kumbar, V. 2016 Calibration and its use in measuring fuel consumption with the can-bus network. In: Acta Universitatis Agriculturae et Silviculturae Mendelianae Brunensis, Vol. 64, Issue 2, p. 503-507.

Report of the company SPS, a. s., transmission network operator in Slovakia

Rybicka, I. et al. 2018 Application of the methodology related to the emission standard to specific railway line in comparison with parallel road transport: a case study, In: MATEC Web of Conferences 244, 03002 (2018), https://doi.org/10.1051/matecconf/201824403002

Skrucany, T., Gnap, J. 2014 Energy intensity and greenhouse gases production of the road and rail Cargo transport using a software in simulate the energy consumption of a train. In: Telematics - support of transport : 14th international conference on Transport systems telematics, TST 2014, Berlin: SPRINGER-VERLAG, ISBN 978-3662-45316-2. - p. 263-272.

Stoilova, S. 2016 Study of the efficiency of motorail trains as a factor in transport development. In: SGEM 2016, BK 2: Political sciences, law, finance, economics and turism conference proceedings, Vol. V. Book Series: International Multidisciplinary Scientific Conferences on Social Sciences and Arts. p. 627-634. Technical annex to the SEAP template instructions document: The emission factors. Document of The European Commission.

Šarkan, B. et al. 2017 Composition of exhaust gases of spark ignition engines under conditions of periodic inspection of vehicles in Slovakia $=$ Skład spalin z silników o zapłonie iskrowym w warunkach okresowych badań pojazdów na Słowacji. In: Przemysl Chemiczny. Vol. 96, No. 3, p. 675680. DOI: $10.15199 / 62.2017 .3 .36$

Vyhláška č. 88/2015 Z.z. Ministerstva hospodárstva Slovenskej republiky, ktorou sa ustanovuje rozsah hodnotenia, spôsob výpočtu a hodnoty energetickej účinnosti zdrojov a rozvodov energie (in Slovak) 